http://dx.doi.org/10.12775/szhf.2014.052

\title{
Andrzej Kucner, Nihilistyczny zwrot w filozofii. Źródła - Nietzsche - Ujścia, Wydawnictwo UWM, Olsztyn 2013, ss. 448
}

Od nihilianizmu do nihilizmu

We wcześniej wydanej książce ${ }^{1}$ Andrzej Kucner zajmował się głównie filozofią Nietzschego, natomiast w publikacji będącej przedmiotem niniejszej recenzji znacząco poszerzył swe pole badawcze, sięgając do ciekawszych koncepcji nowożytnych i współczesnych, pomocnych w jeszcze lepszym zrozumieniu zjawiska europejskiego nihilizmu. Zasadniczo rzecz biorąc, poruszamy się tu w obrębie filozofii niemieckiej, która Kucnerowi jest merytorycznie najbliższa, jednak co rusz natrafiamy na rozważania dotyczące twórczości myślicieli francuskich i rosyjskich, a czasem też anglosaskich. Oczywiście nie obeszło się bez nawiązania do poglądów filozofów reprezentujących rodzime środowisko badaczy nihilizmu. W rzetelnych analizach Kucnera przewija się mnóstwo nazwisk myślicieli, którzy w swojej twórczości jakoś odnieśli się do tego zjawiska. Jedni $\mathrm{z}$ nich znani są historykom idei dobrze, inni słabo. Oprócz filozofów pojawiają się pisarze i osoby wykonujące inne zawody. Trzeba przyznać, że autor książki wykonał wręcz gigantyczną pracę, przesiewając przez sito cały dorobek myśli ludzkiej. Trudno byłoby bardziej precyzyjnie przedstawić dzieje nihilizmu i transformacje tego pojęcia. Spektrum zagadnień zawartych w książce jest bardzo szerokie, ale wszystkie podjęte wątki ogniskują się w problemie nihilizmu. Jeżeli przyjąć, że po Nietzschem nihilizm stał się znakiem rozpoznawczym wszelkiego (humanistycznego) fi-

\footnotetext{
${ }^{1}$ A. Kucner, Friedrich Nietzsche. Źródła i perspektywy antropologii, Wyd. UWM, Olsztyn 2001.
} 
lozofowania, to rozprawa Kucnera jest gruntownym rozrachunkiem z filozofią jako taką, z jej aspiracjami i osiągnięciami.

Książka składa się z trzech części, traktujących kolejno o początkach nihilizmu (Źródła), o nihilistycznej reorientacji myślenia (Nietzsche) i o współczesnych odmianach nihilizmu (Ujścia). Przystępując do systematycznego wykładu na temat historii nihilizmu, Kucner wspomina o nihilianizmie jako zjawisku pokrewnym, jakoś powiązanym, choćby terminologicznie, z interesującym go zjawiskiem nihilizmu. Przyznam, że podczas powtórnej lektury tej rozprawy zacząłem się zastanawiać nad charakterem związku nihilianizmu z nihilizmem. Przeczuwałem bowiem, że mam tu do czynienia - ujmę to w sposób nietzscheański - z „narodzinami nihilizmu z ducha nihilianizmu”. Nie wiem, czy Kucner by się ze mną zgodził, wszak do nihilianizmu odniósł się w sposób dość zdystansowany: „Ów heretycki odłam średniowiecznej teologii najprawdopodobniej nie miał bezpośredniego, genealogicznego związku z późniejszym nihilizmem i toczącymi się wokół niego dyskusjami, ujawnił jednak problematyczny charakter podstawowych dla nihilizmu pojęć nicości i anihilacji” [s. 40]2.

Pozwolę sobie sięgnąć do historii. W 1180 roku nihilianistami nazwano Piotra Lombarda i jego uczniów, którzy twierdzili, że człowieczeństwo Jezusa Chrystusa jest niczym albo - jeszcze dosadniej - Chrystus w swej ludzkiej naturze jest niczym (nikim). Ten gorszący i heretycki, w opinii katolickich teologów, pogląd chrystologiczny głoszony był już wcześniej, choć może w nieco bardziej zawoalowany sposób, przez Piotra Abelarda, którego wykładów słuchał m.in. Lombard. Przypomnę, że Abelard był błyskotliwym myślicielem, wyprzedzającym o kilka stuleci epokę renesansu. W czasie, gdy średniowieczni teolodzy literalnie odczytywali Pismo Święte i stali na straży trywialnego realizmu, Abelard, stosując grecką logikę i dialektykę, alegorycznie interpretował Objawienie i chętnie posługiwał się analogią. Pierwsi zwykle powoływali się na autorytety, drugi - chętnie czynił użytek ze swego rozumu. W pewnym sensie to przywiązanie do racjonalnego dyskursu okazało się jednak nieroztropne. Zamiast głosić, jak należało, że Chrystus jest prawdziwym Bogiem i zarazem prawdziwym człowiekiem, Abelard mówił, że w Chrystusie Bóg posiada człowieka. Z tego też powodu, nie bez racji, oskarżano go o adopcjanizm. Nie da się ukryć, że z punktu widzenia ortodoksji jego podejście do unii hipostatycznej należy uznać za heretyckie. W wielu innych kwestiach jego poglądy także były niepoprawne, np. w etyce zwykle

\footnotetext{
${ }^{2}$ Cytaty z książki Kucnera lokalizuję bezpośrednio w tekście.
} 
były pelagiańskie. Dzisiaj już jednak one nie szokują, lecz raczej skłaniają do głębszego namysłu nad podstawowymi treściami wiary chrześcijańskiej. Szokują tylko, i pewnie zawsze będą szokować, konsekwencje jego specyficznego związku z Heloizą. O ile przed nim Orygenes sam się wykastrował, chcąc się stać czystym dla Królestwa Bożego, czyli w akcie desperacji, o tyle Abelard został wykastrowany za brak czystości myślenia i postępowania lub, najzwyczajniej w świecie, w akcie zemsty. Nie będę rozwijał tego wątku, ponieważ kluczową sprawą ma tu być kwestia nihilianizmu.

Warto się zastanowić, dlaczego rzeczeni Abelard i Lombard zakwestionowali ludzką naturę w Chrystusie. Czy chodziło im o jeszcze większe wywyższenie Boga w jego absolucie i transcendencji, czy raczej chcieli rozdzielić Boga i człowieka, oderwać Stwórcę od rzekomego stworzenia, uwolnić człowieczeństwo spod jarzma boskości, pozbyć się „Wielkiego Brata”. Oczywiście przesadziłem. Obaj panowie pewnie przeraziliby się tym, co im próbuję imputować. Nie powinienem podejrzewać ich o tak radykalny ateizm, ponieważ na pewno wierzyli w Boga, tyle że ich wiara, podobnie jak sytuacja życiowa, była innego rodzaju, pewnie bardziej dramatyczna, znamionująca wewnętrzne rozdarcie i niepewność własnego losu. No właśnie. Zgodnie z poglądami nihilianistów, człowieczeństwo Jezusa było niczym wobec boskości Boga, a więc, jak domniemywam - o ile mogę twórczo rozwinąć tę myśl - człowiek w oderwaniu od Boga jest niczym. Innymi słowy, parafrazując Dostojewskiego, jeśli Boga nie ma (w świecie), to wszystko jest nicością. Z jednej strony, człowiek jest wolny i nikt mu nie każe żyć zgodnie $\mathrm{z}$ religijnymi wymoga$\mathrm{mi}, \mathrm{z}$ drugiej strony, człowiek bierze na siebie wszystkie obowiązki związane $z$ rządzeniem światem $i$, chcąc nie chcąc, cierpi z tego powodu. Wywiedziony z nihilianizmu nihilizm jest tragiczny, a właściwie - nihilista jest tragiczny, osamotniony, bolejący nad sobą i światem. Nie dosyć, że bardzo cierpi, to kręgi nienihilistyczne, czyli religijne, przysparzają mu dodatkowych cierpień, obarczając go winą za zaistniały stan rzeczy. Termin „nihilista”, tak jak „nihilianista”, to etykietka bezbożnika, złoczyńcy i abnegata. Abelard musiał zmagać się z tym piętnem, Lombard w jakiejś mierze również, a inni?

Barucha Spinozę znamy głównie $\mathrm{z}$ tego, że był zwolennikiem panteizmu, jednak dla Friedricha Jacobiego panteizm był przejawem ateizmu, dlatego uznał on Spinozę za nihilistę. Twórca filozofii wiary (Glaubensphilosophie) w podobny sposób potraktował Kanta, Fichtego i Schellinga, a nawet Kartezjusza, który swą koncepcją niezależnej (od Boga) świadomości, zainspirował Kanta i jego następców. Każdemu z nich Jacobi zarzucił nieprawomyślny stosunek do Boga, a więc nihilizm. Nie on jeden wystąpił w charakterze fi- 
lozoficznego inkwizytora. Również Herder w jakiejś mierze przejawiał takie zapędy, wszak krytykował Kanta za to, że jego postulaty moralne, zaprezentowane przez autonomiczny rozum, biorą się z całkowitej pustki, czyli ze świata pozbawionego boskiego prawodawcy. W podobnym duchu, choć skrycie, krytykował Kanta jego rzekomy zwolennik, Daniel Jenisch, którego mierziła nieprawomyślność królewieckiego uczonego w kwestiach religijnych. Ani Herder, ani Jenisch nie dorównywali jednak Jacobiemu w zapalczywości, $\mathrm{z}$ jaką ten gromił faktycznych bądź domniemanych ateistów-nihilistów. Doprowadził on do publicznego sporu o panteizm (Pantheismusstreit), który szybko przerodził się w spór o ateizm (Atheismusstreit), aby na oczach gapiów palić na stosie jeżeli nie samych filozofów, to przynajmniej, w symboliczny sposób, ich bezbożne poglądy. W tym czasie, jak zauważa Steffen Dietzsch, pojęcie „nihilizm” stało się zawołaniem bitewnym. W walce na słowa najbardziej dostało się Kantowi jako faktycznemu inicjatorowi idealizmu transcendentalnego. Ponieważ jednak Kant nie potrafil już wziąć udziału w tym sporze (nawet groteskowo silna wiara Jacobiego nie była w stanie go wskrzesić z martwych i poddać bezpośredniemu osądowi „Świeckiego Oficjum”), celem zmasowanego ataku stał się głoszący kantowskie poglądy Fichte. Przyparty do muru, albo raczej popychany kuksańcami w stronę płonącego stosu, Fichte próbował jakoś się bronić. W końcu uratował życie, ale stracił stanowisko profesora. Jacobi wytoczył też ciężkie działa przeciw Schellingowi, choć nie umiał trafić w złoczyńcę, zapewne z tego powodu, że poglądy tegoż idealisty były, w oczach zwolennika czystej wiary, zestawem sprzeczności i rozmytych argumentów, a więc ruchomym celem. Dzięki temu twórca nieabsolutnej koncepcji absolutu ocalał.

Nihilistyczne przesłanki zawarte są również w utworach Friedricha Hölderlina. Na własną zgubę Hölderlin, tak jak inni poeci romantyczni, stawiał pytania o sens istnienia, jakby zapominając o tym, że przecież Bóg jest tym sensem. Nie ma się co dziwić, że podzielił los własnego bohatera Hyperiona i stał się postacią tragiczną, wewnętrznie wyniszczoną zarazą nihilizmu. Zamiast zaufać Stwórcy i nabrać przekonania o pewności (własnego) istnienia, wolał z pomocą Adamasa wędrować po antycznych bezdrożach i doświadczać mroków nieistnienia. Jego egzystencjalne wahania i troski okazały się doświadczeniem demonicznym, skazującym go na wieczne potępienie, a przynajmniej na niekończące się aberracje umysłowe. W tym miejscu od razu nasuwa mi się skojarzenie z Heglem, którego poglądy, jak mawiał jeden z moich dawnych nauczycieli, to przejaw patologii umysłu ludzkiego. Dlaczego? Dlatego, że (Heglowski) umysł wystarcza sam sobie i tworzy w sobie 
i z siebie jakiś absolut chcący być Bogiem. Oczywiście doskonale zdał sobie z tego sprawę także Jacobi, więc ruszył do ataku na Hegla, czym jednak nie wzburzył wewnętrznego spokoju wybitnego idealisty. Ten bowiem znał już historię sporów Jacobiego ze swoimi poprzednikami i z dużym dystansem podszedł zarówno do poglądów Fichtego, które brzydziły Jacobiego, jak i do poglądów Jacobiego, które zapewne były przedmiotem uwielbienia samego Jacobiego. Hegel, jak to miał w zwyczaju, dialektycznie pojednał oba stanowiska albo raczej zniósł je swym magicznym Aufhebung, czym dał wyraz przekonaniu o finalnym charakterze własnej filozofii, wobec której wszystko inne jest tylko przyczynkarstwem, tyle że przyczynkarstwem koniecznym dziejowo, gdyż bez tezy i antytezy nie byłoby syntezy. Co więcej, Hegel uczynił z nihilizmu właściwy problemat filozoficzny i w ten sposób ostatecznie wytrącił oręż z rąk Jacobiego, który już zupełnie nie wiedział, co ma począć $\mathrm{z}$ tak zabsolutyzowaną nicością.

Następnym w długim szeregu wielkich nihilistów jest Max Stirner. Ten myśliciel w ogóle nie krył swego nihilizmu, tylko otwarcie oznajmił, że swoją sprawę (filozoficzną) oparł na nicości (Ich hab' meine Sach' auf Nichts gestellt). Swoją drogą, Stirner przejął tę zgrabną frazę od Goethego, a Goethe zapożyczył ją z pewnej dość popularnej wówczas pieśni religijnej. Jak widać, krąg nihilistycznego oddziaływania jest szeroki, a jego źródła tkwią w religijności. Gdy chodzi o Stirnera, to wiadomo, że dla niego Bóg był widmem, a więc właściwie czymś nie mającym realnego istnienia, co jednak go męczyło i irytowało samym swym istnieniem w języku i kulturze. Niemniej egoistyczny Jedyny zdecydowanie stanął ponad wszystkimi widmami, za nic je mając, czyli uznając je za nicość. Szkoda, że mimo swej wielkości Stirner marnie skończył, ale taki jest los wszystkich nihilistów. W tym kontekście warto chociaż napomknąć o Feuerbachu, który pewnie zaraził Stirnera swym nihilizmem. Dla Feuerbacha igranie z Bogiem i sprowadzanie go do idei doskonałego człowieka też się źle skończyło. Z powodu radykalnie ateistycznych poglądów pożegnał się z pracą akademicką, osamotniał i popadł w biedę.

Bodaj najbardziej dramatyczne figury nihilizmu pojawiają się w literaturze rosyjskiej, zwłaszcza w twórczości Fiodora Dostojewskiego. Dzieła tego myśliciela obfitują w charakterystyki różnej maści straceńców, którzy nie tylko wątpią w sens życia, ale wręcz wyrzekają się życia. Na przykładzie dysput z udziałem Kiryłowa w Biesach wyraźnie widać, że człowieczeństwo jest niczym, o ile nie zostanie wyniesione do rangi boskości i nie zastąpi boskości Boga. Gdy wreszcie kiedyś tak się stanie, Bóg okaże się niczym, tyle że nie wiadomo, czy nicość Boga kiedykolwiek się ziści, wszak droga do niej wyma- 
ga największego samopoświęcenia człowieka, z rezygnacją z życia włącznie. Wszystko u Dostojewskiego jest bardzo pogmatwane egzystencjalnie, ale taki jest urok jego dzieł. Nie tylko Notatki z podziemia mówią o „podziemnych" ludziach, którzy w ukryciu przed światem i przed samymi sobą nurzają się w nicości niebytu. Także Bracia Karamazow konfrontują nas z mrocznymi podziemnymi lochami, pełnymi nieludzko-ludzkich okropności. Pojawia się w nich nawet wielki inkwizytor, surowo besztający Chrystusa za jego niestosowne mieszanie się do spraw dotyczących wyłącznie człowieka. Ów inkwizytor znacznie różni się od wspomnianego wcześniej Jacobiego, ale być może różnica ta wynika stąd, że jest on znacznie mniej zakłamany. Nie kryje bowiem swej ateistycznej woli panowania nad światem, nie jest wilkiem w owczej skórze, który wykorzystuje religijną wiarę do własnego wywyższania się nad całą resztą rodzaju ludzkiego. Zdumiewa fakt, że w diabelsko mrocznych podziemiach można liczyć na więcej szczerości i uczciwości, niż na ziemi opromienionej boską chwałą. Tam nawet tacy nihiliści, jak Stawrogin, opowiadający się za skrajną autodestrukcją, potrafią wzbudzić szacunek.

Tak oto doszedłem do Nietzschego, który w książce Kucnera wyznacza punkt zwrotny filozofowania. Nietzsche nie tylko jest nihilistą, ale jest kimś, kto zdaje sobie $\mathrm{z}$ tego sprawę i pisze o problemie nihilizmu, a nawet usiłuje się z nim uporać. Wszystko wskazuje na to, że Nietzsche „zaraził się” nihilizmem od Schopenhauera, myśliciela potępiającego świat jako wolę i przedstawienie. Zdaniem tego pesymisty, wola zmusza nas do chcenia tego, czego w rzeczywistości nie chcemy, a przedstawienie zamyka nas w klatce stereotypowych zapatrywań. Jeżeli chcemy zakosztować choć odrobiny wolności, to musimy wyrzec się świata i woli, będącej jego stwórczynią. Nihilizm jest zatem odpowiedzią Schopenhauera na zniewolenie człowieka nieludzką wolą. Nietzsche, gdy zaczął myśleć na własny rachunek, przeorientował tę koncepcję, uznając ją za nihilistyczną. Stwierdził, że świat, w którym żyjemy, jest jedynym miejscem do życia. Zamiast wyrzekać się świata, trzeba go zaakceptować takim, jakim jest, a nawet ukochać go, w szczególności zaś ukochać w nim to, co spontanicznie najbardziej nas od niego odstręcza. Wszystkie życiowe doświadczenia są bowiem niezbędnymi elementami naszego samorozwoju zmierzającego ku nadczłowieczeństwu, czyli człowieczeństwu ze wszech miar wyzwolonemu. Choćby tylko antycypując swą przyszłą wolność, Freigeist chce wzrastać w mocy życia, chce czuć w sobie jak najwięcej woli mocy życia, chce panować nad tym, co chce go więzić i zniewalać.

W takim razie, czy Nietzsche jest nihilistą? I tak, i nie. Niewątpliwie jest on nihilistą w oczach tych, co żyją (albo raczej: wegetują) w pozorze świata 
ukonstytuowanego przez chrześcijaństwo. Powiedzmy sobie wprost: chrześcijanie nazwali Nietzschego nihilistą i wyparli się go po tym, jak Nietzsche uznał ich świat za nihilistyczny i wyparł się chrześcijaństwa. Już Schopenhauer stwierdził, że podstawowym pryncypium etycznym tej religii jest wyrzeczenie. Dobry chrześcijanin wyrzeka się niemal wszystkiego, czym życie wiąże go z tym światem, ponieważ wydaje mu się, że jego przeznaczeniem jest inne życie i inny świat. Mimo podjęcia zdecydowanej krytyki chrześcijańskiej obłudy i zła czynionego przez wyznawców tej religii, Schopenhauer solidaryzował się z propagowaną przez chrześcijan postawą wyrzeczenia. Schopenhauer nie był małostkowy. Mniejsza o racje, jakie stoją za tym, by rezygnować z oferty (woli) życia i świata. Ważne jest to, że się rezygnuje. Nietzsche nie mógłby zgodzić się z taką opinią. Jego swoiście pazerna namiętność życiowa zdecydowanie kłóci się z przejawianą przez Schopenhauera wrogością do życia. Jeśli spojrzeć z tej perspektywy, to Nietzsche nie jest nihilistą. Nie wykluczam, że piszący o nihilizmie Nietzsche, syn pastora i wychowanek Schulpforty, który przestał być chrześcijaninem, świadomie nawiązał do poglądów nihilianistów, widząc $\mathrm{w}$ nich klarowne ujęcie istoty trapiących go dylematów religijno-moralnych. Jeżeli tak się stało, to słynna formuła „Bóg umarł" oznaczałaby antycypację odnowienia życia w ziemskim świecie po unicestwieniu transcendentnych zaświatów. Z kolei formuła „Dionizos przeciw Ukrzyżowanemu" oznaczałaby pełne mocy opowiedzenie się za życiem i przeciw umieraniu. Byłaby ona wiecznym „Tak” dla całościowo pojętego i doświadczanego życia. W tym ujęciu afirmowana przez Nietzschego dionizyjskość jest próbą alternatywnego zdeifikowania oraz autentycznego uczłowieczenia świata i, w konsekwencji, przywrócenia mu wartości. Chyba nic nie stoi na przeszkodzie, aby przyjąć, że wspomniane formuły nie są wyrazem nihilizmu, lecz są sztandarowymi hasłami walki z nihilizmem.

Heidegger poświęcił bardzo dużo czasu na zgłębianie filozofii Nietzschego. Prowadził też na jej temat wykłady, których pokłosiem jest monumentalne, dwutomowe dzieło Nietzsche. Twórczość (rzekomo) ostatniego europejskiego metafizyka pasjonowała go tak dalece, że można by mówić o niemal nabożnym stosunku Heideggera do Nietzschego. Swoją drogą, przedmiotem fundamentalno-ontologicznego namysłu Heideggera stali się również bogowie - Bóg judeochrześcijański oraz bogowie starożytnych Greków i Rzymian. Gdyby Jacobi żył w czasach Heideggera, to niewątpliwie „ochrzciłby” go mianem nihilisty. Autor Bycia i czasu był bowiem przekorny i czasem niepoprawny w swych ocenach boskości i religijności. Nie podobało mu się zwłaszcza spętanie ontologii teologią i uprawianie jej pod dyktando absolutnych pra- 
$\mathrm{w}(\mathrm{d})$, co doprowadziło do powstania niby naukowej, ale jednak bez-myślnej metafizyki nowożytnej. Ponadto, dociekając natury bycia bytu, Heidegger chętnie odwoływał się do poezji Hölderlina, co jest kolejnym symptomem nihilizmu. Na dodatek dużo pisał o nihilizmie, zarówno w kontekście badań nad filozofią Nietzschego, jak i podczas dookreślania fundamentów ontologii (jak wiadomo, bycie kojarzył z nicością). Ani chybi nihilistą był także Sartre, nawiązujący do rozstrzygnięć Heideggera w kluczowych kwestiach własnej filozofii. Ten bezbożnik nie tylko umieścił pojęcie „nicość” w tytule swego głównego dzieła, ale w samym tym dziele przedstawił swego rodzaju dowód na nieistnienie Boga (wewnętrzna sprzeczność bytu-w-sobie-dla-siebie). Rezultatem fenomenologiczno-ontologicznego namysłu Sartre’a nad światem jest świat człowieka, w którym człowiek pod nieobecność najwyższego rękodzielnika samodzielnie powołuje do istnienia wszelkie byty, włącznie z sobą - bytem egzystującym, nie posiadającym uprzednio określonej istoty. Czy możliwy jest jeszcze bardziej radykalny nihilizm?

O ile dawni nihiliści głosili swoje poglądy na tle doktryn nienihilistycznych, o tyle współcześni nihiliści albo skrzętnie pozbywają się takiego tła, albo otwarcie szydzą ze wszystkiego, co znajduje się w tle, czyli ze wszystkiego, w czym jest choćby odrobina transcendencji bądź odblask jakiejś absolutnej wartości. Ponowoczesność (postmodernizm) okazuje się nie tylko epoką następującą po epoce nowoczesności (modernizmu), ale także sposobem myślenia dyskredytującym myślenie nowoczesne. Praktycznie rzecz biorąc, w myśli nowoczesnej jeszcze o coś chodziło, natomiast w myśli ponowoczesnej już o nic nie chodzi lub - ujmę to pozytywnie - chodzi o nic. Owo „nic” to nic innego jak nicość. Gianni Vattimo bez ogródek nicestwi wartość Heideggerowskiego bycia i proklamuje czasy spełnionego nihilizmu, w których już nic nie ma sensu. Sensu nie ma zwłaszcza byt ludzki, a wraz z nim nie ma go także filozoficzny namysł nad światem, wszak myślenie ponowoczesne wyrzekło się racjonalności, uznając ją za nowoczesną manierę, która definitywnie odeszła do lamusa. Puste miejsce po logicznych analizach i metafizycznych dociekaniach zostało wypełnione czystą retoryką, czyli - paradoksalnie - pustosłowiem. Jean Baudrillard nie waha się twierdzić, że żyjemy na pustyni, będącej pozorem rzeczywistości albo domeną symulakrów. Już nic nie jest rzeczywiste, ponieważ wszystko stało się hiperrzeczywiste. Nie dajmy się zwieść owemu „hiper”. Tutaj nie wywyższa się rzeczywistości, tylko czyni z niej największą abstrakcję. Dobrze widać to na przykładzie Boga, który, wedle Baudrillarda, nie umarł, jak pisał Nietzsche, lecz stał się hiperrzeczywisty. Umrzeć może ktoś, kto żył, natomiast hiperrzeczywistym może stać się coś, 
czego de facto nie było. W gruncie rzeczy - o ile w świecie pozbawionym sensu wypada jeszcze posługiwać się pojęciem rzeczy - wszystko jest hiperrzeczywiste, tj. nie ma właściwego bytu ani bycia skrywającego się za bytem, ani niczego innego, gdyż samo to jest niczym, czyli nicością. Jedyne, co pozostało na placu filozoficznego boju, to nicość. Wydaje się, że po przelotnej fascynacji niektórych środowisk po(st)nowoczesną retoryką też już nic nie zostało. Najpewniej ponowoczesność została unicestwiona przez nicość.

Jak moje nienihilistyczne, choć nie fundamentalno-religijne dywagacje na temat nihilizmu mają się do książki Kucnera o nihilizmie? Mógłbym odpowiedzieć, że mają się symulakrycznie, ale jako zwolennik modernizmu powiem, że warunkiem możliwości ich zaistnienia była lektura rozprawy Kucnera. Bez niej, tj. bez tejże rozprawy, chyba nie umiałbym tak prosto przedstawić sobie dziejów nihilizmu. Aliści Kucner nie poszedł na skróty. Z wnikliwością sumiennego badacza wydobył na powierzchnię dyskursu wszystko, co miało jakikolwiek związek z nihilizmem. W efekcie powstało dzieło niemalże encyklopedyczne - oczywiście w dobrym tego słowa znaczeniu, nawiązującym do oświeceniowej, systematycznej i metodycznej roboty encyklopedystów. Wydaje mi się jednak, że Kucner, jako myśliciel „oświeceniowy”, mógłby stwierdzić, iż problem nihilizmu staje się dopiero wtedy zrozumiały, gdy zostanie osadzony w kontekście rozważań na temat Boga i powiązany z problemem nihilianizmu.

Moim zdaniem, zbyt ogólnikowa jest „klasyczna” genealogia nihilizmu, reprezentowana m.in. przez Alberta Camusa, Ottona Pöggelera i Kucnera, wedle której „właściwej genezy pojęcia nihilizmu, użytego w sensie filozoficznym, należy szukać w osiemnasto- i dziewiętnastowiecznych sporach, rozwijających się głównie wokół i w obrębie niemieckiego idealizmu” [s. 41]. Zgadzam się z opinią, że dzięki Heglowi nastąpiło pogłębienie rozumienia nihilizmu, jednak trudno mi przystać na to, że bodaj największym osiągnięciem wielkiego idealisty było „osadzenie nihilizmu w perspektywie stricte filozoficznej, uczynienie zeń autonomicznego problematu filozoficznego” [s. 41]. Śmiem twierdzić, że Heglowski system nie tylko jest ufundowany na refleksji teo-logicznej, ale w zasadzie jest filozoficzną wykładnią zagadnień religijnych. Być może nawet Hegel, będąc krypto-teologiem, był także krypto-nihilianistą. A jak to jest z Nietzschem, myślicielem dokonującym - jak pisze Kucner - nihilistycznego zwrotu w filozofii? Wydaje się, że o ile Nietzsche różni się od Hegla tym, że nie przekształcił doktryny chrześcijańskiej w system filozoficzny, tylko ją zdecydowanie odrzucił, o tyle jednak łączy go z Heglem to, że poniekąd powtórzył jego religijny eksperyment, nadając bosko- 
ści nowe znaczenie. Owa „różnica i powtórzenie”, niezależnie od upodobań filozoficznych i kontekstu poznawczego, ma do dzisiaj istotne znaczenie dla człowieka starającego się właściwie określić swoje miejsce w świecie. Wprawdzie dziwnie to zabrzmi, ale podzielam opinię Bruna Hillebranda, zdaniem którego „Jacobi trwale splótł ze sobą pojęcia idealizmu, ateizmu oraz nihilizmu" [s. 47]. Eufemizmem jest stwierdzenie, że nie czuję sympatii do Jacobiego. Zdaję sobie jednak sprawę z tego, że tenże Jacobi - nie ważne, jak oceniam jego intencje i sposób postępowania - dobrze wiedział, o co w istocie chodzi w nihilizmie, i pewnie także wiedział - nawet jeśli tego wyraźnie nie powiedział - że nihilizm wywodzi się z nihilianizmu. Summa summarum, nihil(ian)izm nie jest problemem stricte filozoficznym, lecz jest problemem stricte ludzkim, powstałym w wyniku konfrontacji człowieka z rzeczywistością o najbardziej żywotnym dlań znaczeniu. Dałoby się rzec, że mamy tu do czynienia $z$ fundamentalnymi problemami filozofii życia albo antropologii kultury, zależnie od tego, jak poważnie traktuje się jedną bądź drugą dyscyplinę.

Rozprawa Kucnera naprawdę daje do myślenia. Gorąco polecam ją wszystkim osobom chcącym żyć świadomie w odwartościowanym świecie.

Henryk Benisz 